\title{
A case of abortion consequent upon infection with Brucella abortus biotype 2
}

\author{
PAULINE M. POOLE, D. B. Whitehouse, AND MARGARET M. Gilchrist
}

From Chester Public Health Laboratory and Wrexham Hospitals

SYNOPSIS The case described here is that of young primigravida in normal health who, on serological evidence, contracted acute brucellosis, and subsequently aborted spontaneously, $\mathrm{Br}$. abortus biotype 2 being isolated from the amniotic fluid.

Little is known of the part played by infection with $B r$. abortus as a cause of abortion in the human species. Several writers associate abortion with the presence of clinical and serological evidence of infection (Simpson and Fraizer, 1929; deCarle, 1931; del Vecchio, 1936; Williamson, 1944). Br. abortus has on occasion been isolated from foetal and placental extract after abortion (Carpenter and Boak, 1931). However, Huddleson (1943) states that there is no tendency to abortion in ordinary cases of brucellosis but where there is a prolonged high temperature, abortion is likely. Likewise Spink (1956) states that there is no definite evidence that brucellosis is more likely to result in abortion than infection with any other species of bacteria.

\section{Methods}

\section{SEROLOGICAL}

Tests carried out routinely for evidence of infection with $\mathrm{Br}$. abortus are (1) the standard agglutination test; (2) the mercaptoethanol test, that is, agglutination in the presence of 2 mercaptoethanol; (3) the complement-fixation test; and (4) the antihuman globulin (Coombs) test (AHG) for non-agglutinating antibodies, all as described by Bradstreet, Tannahill, Pollock, and Mogford (1970). The suspension of $B r$. abortus used in the first three tests was that supplied by the Standards Laboratory, Central Public Health Laboratory, London. The suspension used in the Coombs test was that supplied by the Central Veterinary Laboratory, Weybridge.

INTERPRETATION OF SEROLOGY

The tests used are chosen to reveal the presence of the different immunoglobulins. In acute brucellosis, heavy IgM (macroglobulin) and light IgG (microReceived for publication 16 June 1972. globulin) are both present (Coghlan and Weir, 1967). IgM readily agglutinates in the standard agglutination test. It is destroyed by mercaptoethanol. IgG may or may not be demonstrable by the same test. It is not destroyed by mercaptoethanol. If treatment of the serum with mercaptoethanol results in an absent or much reduced titre, compared with that in the standard agglutination test, this indicates the presence of IgM. In brucellosis, on the other hanf IgG, unlike IgM, readily fixes complement and it presence is most satisfactorily demonstrated by the method.

When acute brucellosis responds successfully to treatment, the IgG titres fall or disappear after a few months but IgM may persist for many years. On the other hand, in cases of chronic brucellosis or in asymptomatic persons with high antibody levels resulting from constant re-exposure to infection, IgG but not IgM is demonstrable. The AHG reveals non-agglutinating immunoglobulins. These may be either IgG or IgA. In brucellosis the presence of IgA is associated with skin sensitization and is frequently found in veterinary surgeons with skin rashes resulting from contact with the products of conception in aborting cows. It does not fix complement nor does it agglutinate readily.

\section{BACTERIOLOGY}

Five $\mathrm{ml}$ of amniotic fluid was cultured by the Castañeda technique (Ruiz Castañeda, 1947). The small Gram-negative coccobacillus isolated on subculture to 'chocolate agar' conformed with the definition of the genus Brucella and was identified as to species and biotype according to the classification determined by the technical report of the FAO/WHO Expert Committee on Brucellosis (1964). Tests for dye sensitivities were carried out by the method of Cruickshank (1948). 


\section{Case History}

On 7 June 1971 a 24-year-old primigravida attended a routine antenatal clinic. She was assessed as of 13 weeks' gestation, obstetrically normal, and in good health. Apart from appendicectomy in 1969 her previous health had been uneventful. She was the wife of a farmer with cows in his herd known to be serologically positive to $\mathrm{Br}$. abortus. There was a history of a single abortion in a cow two years previously. The patient had assisted at calving at various times and she drank raw milk. Solely on the grounds of environmental exposure her blood was submitted to the laboratory, query brucellosis. The results of the tests carried out on this sample were standard agglutination test 10 240: mercaptoethanol 320; complement-fixation 320; AHG 20480 (all titres being expressed as reciprocals of serum dilutions).

The titres were interpreted in the laboratory as diagnostic of acute brucallosis, IgG, IgM, and nonagglutinating antibody all being present. Intensive inquiries were made but no symptoms or signs were elicited to support the diagnosis clinically. Blood culture was not carried out. In the absence of clinical evidence of infection and the contraindication to the use in pregnancy of tetracyclines and other antibacterial agents effective in the eradication of brucellosis, no treatment was given. She continued in good health; further serological tests were carried out on 14 July when the titres were standard agglutination test 5 120: mercaptoethanol 1280 : complementfixation 160: and AHG 40960 . On comparison with the first sample these showed a fourfold rise in the mercaptoethanol test indicating an increase in the amount of agglutinating IgG. Titres in the other tests showed no significant change.

On 21 July the patient was admitted to a different hospital as a case of inevitable abortion at 18 weeks. She reported that there had been a pink discharge from the vagina for the previous three days, followed by the passage of bloodstained mucus. She had also had some irregular low abdominal pains. On examination her temperature was $38^{\circ} \mathrm{C}$ with a pulse rate of 108. Her blood pressure was $100 / 70$ and there were no abnormal signs in the heart or lungs. Abdominal examination showed the uterus enlarged to the size expected at 18 weeks with some tenderness at the fundus. On vaginal examination the cervix was effaced and dilated to 1 centimetre. Intact membranes were palpable. As there had been no further progress with the abortion by 22 July an oxytocin infusion containing 10 units in 1 litre of dextrose saline was commenced. Regular uterine contractions began and after five hours she aborted the foetus, intact in its membranes, together with an infarcted and ragged placenta. Examination of the products indicated that the placenta was incomplete and as retained products had not been passed after four hours the uterus was explored under anaesthesia.

Examination of the pregnancy revealed a foetus of healthy appearance and a ragged infarcted placenta. This was sent to the laboratory for bacteriological investigation. Culture of the amniotic fluid yielded Br. abortus biotype 2 (Table).

Treatment with streptomycin and tetracycline was begun. The patient remained pyrexial for a further 48 hours after which her temperature settled to normal levels. Breast congestion was relieved by the administration of stilboestrol $5 \mathrm{mg}$ tds. Her haemoglobin after operation was $10.8 \%$. The patient's condition had improved sufficiently by 29 July to discharge her home.

A third specimen of blood was examined on 4 August after two weeks' treatment. Titres at this time were standard agglutination test 5120 , mercaptoethanol 1280 , complement-fixation 640 , and AHG 5 120. Complement-fixing IgG had risen. Unfortunately no test had been carried out at the time of abortion with which to compare this result. Treatment with streptomycin was continued until 14 August and with tetracycline until 3 September.

When seen for a postoperative follow up on 2 September the patient had no symptoms but had not yet had a period. Her general condition was normal. Vaginal examination showed normal involution of the pelvic organs. A fourth specimen of blood taken on 10 September showed a slight fall in all titres except for the AHG which was higher than on the previous test-standard agglutination 2560 , mercaptoethanol 640 , complement-fixation 320 , and AHG 20480.

Response to treatment was, however, demonstrated in a fifth specimen of blood submitted on 19 October. At that time all titres had fallen, that on complement-fixation dramatically, indicating that

\begin{tabular}{|c|c|c|c|c|c|c|}
\hline \multirow{2}{*}{$\begin{array}{l}\mathrm{CO}_{2} \\
\text { Requirement }\end{array}$} & \multirow{2}{*}{$\begin{array}{l}\mathrm{H}_{2} \mathrm{~S} \\
\text { Production }\end{array}$} & \multicolumn{2}{|c|}{ Growth on Dyes } & \multicolumn{2}{|c|}{ Agglutination with Monospecific Sera } & \multirow{2}{*}{$\begin{array}{l}\text { Lysis by Abortus } \\
\text { Bacteriophage at } \\
\text { RTD }\end{array}$} \\
\hline & & Thionin & Basic Fuchsin & Abortus & Melitensis & \\
\hline+ & + & - & - & $\div$ & - & - \\
\hline
\end{tabular}

Table Characteristics of $\mathrm{Br}$. abortus biotype 2 isolated from amniotic fluid 
the infection was well under control if noteliminated, standard agglutination 1280 , mercaptoethanol 20, complement-fixation 20, and AHG 1280 ).

\section{Discussion}

Absolute proof of infection requires isolation of a causative organism. In human brucellosis this occurs relatively rarely, diagnosis of the infection usually being made on a combination of clinical and serological evidence. Since antibodies, sometimes at very high titres, are not infrequently found in apparently healthy persons, environmentally exposed, their presence and their nature must be observed with caution before a diagnosis of active infection is made. When blood from the patient under consideration was first examined and both raised IgG and IgM antibodies were found, a laboratory diagnosis of acute active brucellosis was made. This was confounded by the complete absence of clinical symptoms or signs of infection. The eventual abortion and isolation of the causative organisms from the amniotic fluid, however, proved the validity of the serological interpretation.

Apart from the rarity of brucellosis as a proved cause of abortion, it is the lack of clinical evidence of infection in the mother which makes this case of such interest, although inapparent maternal infection has also been described in cases of abortion associated with brucellosis by del Vecchio (1936) and in the case of Carpenter and Boak (1931). Likewise Maschio and Ventura (1967) describe a foetus with a miliary infection with $\mathrm{Br}$. melitensis in which theonly maternal symptom was leucorrhoea, there being no serological evidence to support the diagnosis. In pregnant cows there is known to be a predilection of $B r$. abortus for foetal rather than adult tissue. This has been proved to be due to the presence of erythritol (Smith, Williams, Pearce, Keppie, Harris-Smith, Fitz-George, and Witt, 1962), a constituent of normal ungulate foetal and placental tissue and of foetal origin (Keppie, Williams, Witt, and Smith, 1965). These authors were unable to find erythritol in human placental or foetal tissue, and postulated this as a reason why Br. abortus in the human mother does not usually produce the overwhelming infection of the placenta and foetal tissue found in bovine abortion. The placental necrosis in the present case might, however, be compared with the placentitis demonstrable in cows and othe susceptible species where brucellosis occurs in ? localized form. Unfortunately no tests for erythrito were made so that whether there are instances inf which it is present in human foetal material of whether some other agent may be responsible for the localization of the infection remains unknown. If would seem reasonable, however, that where there is serological evidence of acute active infection witk $B r$. abortus in a pregnant woman, whether or not the disease is clinically apparent, a full course of treatment should be given notwithstanding the contraindications to the general use of certain antis biotics in pregnancy.

We should like to thank Mr S. Bender for initiating the original diagnosis and for the early clinica $f_{\infty}$ history and Dr D. J. H. Payne of the Portsmoutho Public Health Laboratory for confirming the biotypeo

References

Bradstreet, C. M. P., Tannahill, A. J., Pollock, T. M., and Mogford H. E. (1970). Intradermal test and serological tests in suspecte吕 Brucella infection in man. Lancet, 2, 653-656.

Carpenter, C. M., and Boak, R. (1931). Isolations of Brucella abortus from a human fetus. J. Amer. med. Ass., 96, $1212-1216$.

Coghlan, J. D., and Weir, D. M. (1967). Antibodies in human bruceđo N sis. Brit. med. J., 2, 269-271.

Cruickshank, J. C. (1948). A simple method for testing dye sensit of Brucella species. J. Path. Bact., 60, 328-329.

deCarle, D. W. (1931). Premature labor in a case of undulant ferer Proc. Mayo Clin., 6, 469-471.

Huddleson, I. F. (1943). Brucellosis in Man and Animals, 2nd ed Commonwealth Fund, New York.

Joint FAO/WHO Expert Committee on Brucellosis (1964). Fourth report. Tech. Rep. Ser. Wld Hlth Org., No. 289.

Keppie, J., Williams, A. E., Witt, K., and Smith, H. (1965). The role of erythritol in the tissue localization of the brucellae. Brit.J. exp? Path., 46, 104-108.

Maschio, C., and Ventura, T. (1967). Granulomatosi brucellare्ठ fetale miliarica diffusa con leptomeningite della base dell encefalo e del midollo spinale. Riv. Anat. pat., 32, 211-230.

Ruiz Castañeda, M. (1947). A practical method for routine bloođ cultures in brucellosis. Proc. Soc. exp. Biol. (N.Y.), 64, 114-1150

Simpson, W. M., and Fraizer, E. (1929). Undulant fever: report of 633 cases occurring in and about Dayton, Ohio. J. Amer. med. Ass. 93, 1958-1965.

Smith, H., Williams, A. E., Pearce, J. H., Keppie, J., Harris-Smith P. W., Fitz-George, R. B., and Witt, K. (1962). Foetal erythritol: a cause of the localization of Brucella abortus in bovine contagious abortion. Nature (Lond.), 193, 47-49.

Spink, W. W. (1956). The Nature of Brucellosis. University of Minne sota Press, Minneapolis.

del Vecchio, G. (1936). Brucellosi e gravidanza nella specie umana inchiesta in terra di Bari. Difesa soc. $15,606-615$

Williamson, A. R. H. (1944). Abortion in Brucella abortus fever. Brit. med. J., 1, 752. 